OPEN ACCESS

Edited by:

Upendra Kumar

National Rice Research Institute (ICAR), India

Reviewed by:

Dilfuza Jabborova,

Academy of Sciences Republic of

Uzbekistan (UzAS), Uzbekistan

M. Manjunath,

Central Research Institute for Dryland

Agriculture (ICAR), India

*Correspondence:

Rajesh R. Waghunde

rajeshpathology191@gmail.com

Specialty section:

This article was submitted to

Plant-Soil Interactions,

a section of the journal

Frontiers in Agronomy

Received: 02 August 2021 Accepted: 17 November 2021

Published: 14 December 2021

Citation:

Waghunde RR and Sabalpara AN (2021) Impact of Pseudomonas spp. on Plant Growth, Lytic Enzymes and Secondary Metabolites Production.

Front. Agron. 3:752196

doi: $10.3389 /$ fagro.2021.752196

\section{Impact of Pseudomonas spp. on Plant Growth, Lytic Enzymes and Secondary Metabolites Production}

\author{
Rajesh R. Waghunde ${ }^{1 *}$ and Ambalal N. Sabalpara ${ }^{2}$ \\ ${ }^{1}$ Department of Plant Pathology, College of Agriculture, Navsari Agricultural University, Bharuch, Gujarat, India, ${ }^{2}$ Navsari \\ Agricultural University, Navsari, Gujarat, India
}

Seven strains of Pseudomonas spp. were isolated from the south Gujarat region of India. Antifungal and bacterial activities of bacterial strains were evaluated against important plant pathogens in vitro, among them, PaRS was found most effective. The indole acetic acid production was recorded in all isolated Pseudomonas spp. Seed treatment with PaRS at $6 \mathrm{~g} / \mathrm{kg}$ was significantly superior over other treatments for plant growth promotion (germination, shoot and root length, shoot and root weight, vigor index, and both shoot and root colonization) under standard roll towel method and pot conditions. The maximum siderophore production was observed in PaRS and medium production in PfRB, PaNS, and PfNC. PaNS and PaRS strains recorded strong HCN production but moderate production recorded in PaWP, PaWS, and PfNC. The maximum phosphate solubalization zone (22 $\mathrm{mm}$ ) was found in PaRS. PaRS recorded maximum chitinase, B1,3-glucanase activity, hydrogen cyanide, and salicylic acid production as compared to other strains.

Keywords: Pseudomonas, plant growth, secondary metabolites, enzymatic activity, colonization

\section{INTRODUCTION}

Various agrochemicals are available in the market for the management of pests and diseases, and a few of them cause harmful effects on the environment. Recently, consumers are demanding organic products in the world market which are safer for consumption (Kumar, 2009; Waghunde et al., 2016, 2021; Morales-Cedeño et al., 2021). The higher input cost, economical losses from pests and disease, climate change, as well as the risk of invasive pests resulted in a search for alternate low cost techniques and management practices (Waghunde et al., 2021). Biological control is an effective, eco-friendly, and economical practice, and the best alternative to agrochemicals for pest management (Iftikhar et al., 2020). The microorganism is one of the smartest living organisms on the earth because of its survivability under extreme conditions, andpresently many beneficial microorganisms are utilized for plant disease management (Shelake et al., 2019; Waghunde et al., 2021). The different agriculturally important microbes like Trichoderma, Bacillus, Serratia, Pseudomonas spp. were used to manage plant pathogens i.e., Ganoderma boninense, Fusarium oxysporum f. sp. cubense, Burkholderia glumae, Xanthomonas oxyzae pv. Oryzae, Pseudomonas syringae, Pectobacterium carotovorum, Ralstonia solanacearum, Fusarium oxysporum f. sp. cucumerinum, Sclerotium rolssii, and Pyricularia oryzae, and also increase plant growth (Kishore et al., 2005a; Durairaj et al., 2017; Islam et al., 2018; Muniroha et al., 2019; Wong et al., 2021). The plant-growth-promoting bacteria comprising a different group has a beneficial effect on the host through the direct and indirect mechanism which not only helps plant growth but also 
reduces plant disease (Durairaj et al., 2017; Islam et al., 2018; Wong et al., 2021). The maximum emphasis should be given to identification, characterization, and mass multiplication of native bioagents for the promotion of sustainable agriculture throughout the world (Waghunde et al., 2016; Verma et al., 2019, 2020). The successful use of native strains of Pseudomonas as bioinoculants for applications on crops requires these strains to compete satisfactorily with the indigenous microflora of soil, to survive, and to persist in adequate viable-cell numbers in the rhizosphere (Fischer et al., 2010). Some bioagents like Pseudomonas have the potential to manage a diverse group of pathogens by releasing volatile and non-volatile compounds (Kishore et al., 2005b).

The objectives of the present study were to isolate Pseudomonas spp. and in vitro evaluation against different important plant pathogens. The secondary metabolites production with the enzymatic activity of bacterial strains was also studied during the investigation.

\section{MATERIALS AND METHODS}

\section{Isolation and in vitro Screening}

The Pseudomonas strains were isolated during 2011-2012 from the Waghai region of south Gujarat, India which is especially known for organic farming. It is situated at a cross-section of latitude of $20.77^{\prime} \mathrm{N}$ and longitude of $73.50^{\prime} \mathrm{E}$ under the agro-climatic zone of the south Gujarat heavy rainfall zone, agroecological situation-I. The location, habitat, crop, and code of bacterial strains are mentioned in Table 1.

The bacterial strains were subjected to identification and based on the morphological, biochemical, and physiological characterization, among them four bacterial strains were identified as Pseudomonas aeruginosa (PaWP, PaWS, PaRS, and PaNS) and three as P. fluorescens (PfWN, PfRB, and PfNC).

The bacterial strains were evaluated against important fungal pathogens i.e., Pyricularia oryzae Cavara, Colletotrichum falcatum Went, Fusarium moniliformae Sheldon, Macrophomina phaseolina (Tassi) Goud, Sclerotium rolfsii Sacc., Pythium aphanidermatum (Eds.) Fitz., Pestalotiopsis anacardia, and Lasiodiplodia theobromae Pat.; and bacterial pathogens i.e., Xanthomonas axonopodis pv. oryzae, Xanthomonas axonopodis pv. Malvacearum, and Xanthomonas axonopodis pv. citri in vitro by dual culture (Dennis and Webster, 1971) and paper disc method (Thornberry, 1950), respectively. Seven days old mycelia disc $(5 \mathrm{~mm})$ of pathogen were placed on the opposite side of bacterial strain streaked (Vidhyasekaran et al., 1997). The plates were incubated at room temperature $\left(25 \pm 2^{\circ} \mathrm{C}\right)$ for 5 days and the radial growth of pathogens in treated and control plates were recorded. Each treatment was repeated three times. Two days old culture of bacterial pathogens was spread with the help of a sterile spreader on sterilized nutrient agar Petri plates. Three sterile $5 \mathrm{~mm}$ filter paper discs were dipped in the cell suspension $\left(10^{8}\right.$ cells $\left./ \mathrm{ml}\right)$ of Pseudomonas spp. and placed on a Petri plate spread with the pathogen. Three Petri plates were kept for each pathogen. Filter paper discs without dipping in Pseudomonas spp. considered as control. The Petri plates were incubated at room temperature $\left(25 \pm 2^{\circ} \mathrm{C}\right)$ for 2 days and inhibition was recorded.

\section{Plant Growth Promoting Activity of PaRS Roll Towel Method}

An experiment was conducted to assess the efficacy of PaRS on seed germination and plant growth promotion ability by the standard roll towel method (ISTA, 1985) in the growth chamber.

The seeds of finger millet variety GN-4 were sterilized with $1 \%$ sodium hypochlorite $(\mathrm{NaOCl})$ solution for 2-3 min then washed 2-3 times and air-dried for 15 mins. A talc and vermicompostbased formulation of PaRS applied to finger millet seed at 4, 6, and $8 \mathrm{~g} / \mathrm{kg}$ seeds $\left(10^{7} \mathrm{cfu} / \mathrm{g}\right)$ and without PaRS was considered as control. Five repetitions of each treatment were made. One sheet of germination paper was wetted by distilled water and 25 seeds of the respective treatment were placed on the first sheet evenly. The rolled papers were incubated in a seed germinator at $25 \pm$ $2^{\circ} \mathrm{C}$ and $95 \pm 3 \%$ RH. Sterile water was added to maintain paper towel moisture. The emergence of seedlings from the grain was considered as successful germination and recorded after 7 days. Three seedlings were taken at random from each replication and the length of root and shoot were measured along with fresh root and shoot weight after 7 days. Plant growth promotion of finger millet seedling was assessed using Vigour Index (VI).

$\mathrm{VI}=$ percent germination $\times$ mean total length of seedling (root length + shoot length) (Baki and Anderson, 1973).

The PaRS colonization was assessed as per the method suggested by Papavizas and Davey (1960). Three seedlings from each replication were selected, a root and shoot portion was cut and transferred to a test tube containing $10 \mathrm{ml}$ sterile water. After thorough shaking, the population of PaRS in the suspension was estimated by the dilution plate method using a $\mathrm{KB}$ medium containing rifamycine $(195 \mu \mathrm{g} / \mathrm{ml})$, penicillium $\mathrm{G}(90 \mu \mathrm{g} / \mathrm{ml})$, actinomycin D $(100 \mu \mathrm{g} / \mathrm{ml})$, and streptomycin D $(30 \mu \mathrm{g} / \mathrm{ml})$. Fluorescence of the colony was checked under UV light. Three Petri dishes for each dilution and five replications were maintained. The colony forming unit was enumerated at $10^{4}$ dilutions. The root samples were weighed and the population of bacteria was expressed per gram of root samples.

\section{Pot Study}

The treatment details in the roll towel method were repeated in pot conditions to validate the efficacy in pots under greenhouse conditions. The experiment was conducted in the greenhouse of the Department of Plant Pathology, N.M. College of Agriculture, Navsari Agricultural University, Navsari, Gujarat, India during the year 2011-2012. Five repetitions of each treatment were made and without PaRS treated seeds, which served as control. Plastic pots $(300 \times 300 \mathrm{~mm})$ were used and filled with sterilized soil. Finger millet (GN-4) seeds were treated with PaRS formulation $\left(10^{7} \mathrm{cfu} / \mathrm{g}\right) 4,6$, and $8 \mathrm{~g} / \mathrm{kg}$ seeds, and eight seeds were sown in each pot. Five seedlings of 4, 6, and $8 \mathrm{~g} / \mathrm{kg}$ PaRS formulation treated seeds were kept in each pot for the pot experiment. The germination was recorded initially and the number of leaves, plant height, and root colonization (cells/g) were recorded at 15 day intervals. The root portion was cut and washed gently in $100 \mathrm{ml}$ of sterile water in an Erlenmeyer flask to remove soil. CFU was enumerated at $10^{6}$ dilution as per the procedure given by Papavizas and Davey (1960). 
TABLE 1 | Sampling site location, habitat and code of bacterial strains used during experiment.

\begin{tabular}{|c|c|c|c|c|}
\hline Sr. No. & Sampling site & Habitat & Geographical status & Code \\
\hline 1 & Hill Millet Research Station, & Paddy (Near to root zone) & $20.77^{\prime} \mathrm{N} 73.50^{\prime} \mathrm{E}$ & PaWP \\
\hline 2 & Navsari Agricultural University, Waghai & Nagli (Near to root zone) & $20.77^{\prime} \mathrm{N} 73.50^{\prime} \mathrm{E}$ & PfWN \\
\hline 4 & $\begin{array}{l}\text { Hill Millet Research Station, } \\
\text { Navsari Agricultural University, Rambhas }\end{array}$ & Banana (Near to root zone) & $20.80^{\prime} \mathrm{N} 73.62^{\prime} \mathrm{E}$ & PfRB \\
\hline 7 & $\begin{array}{l}\text { Livestock Research Station, Navsari Agricultural } \\
\text { University, Navsari }\end{array}$ & Castor (Near to root zone) & $20.95^{\circ} \mathrm{N} 72.93^{\circ} \mathrm{E}$ & PfNC \\
\hline
\end{tabular}

\section{Qualitative and Quantitative Estimation of Siderophore}

All the glassware used in the siderophore assays and in the preparation of the Chrome Azurol S blue agar medium (CAS) were soaked in a $2 \mathrm{~N} \mathrm{HCl}$ solution for $24 \mathrm{~h}$. After removing from the acid solution, the glassware was invariably washed with double distilled water. The rest procedure followed as per Schwyn and Neilands (1987).

\section{Preparation of CAS for the Detection of Siderophore}

For one liter of blue agar CAS medium, $60.5 \mathrm{mg}$ Dehydrated Chromo Azurol S (Hi Media) was dissolved in $50 \mathrm{ml}$ water and mixed with $10 \mathrm{ml}$ of iron solution $\left(1 \mathrm{mM} \mathrm{FeCl} 3 \cdot 6 \mathrm{H}_{2} \mathrm{O}\right.$ in $10 \mathrm{mM} \mathrm{HCl}$ ). While stirring, a $40 \mathrm{ml}$ aqueous solution containing 72.9 mg cetyl trimethyl ammonium bromide was slowly added, with continuous stirring, and the final solution was autoclaved. King's B agar medium was prepared with PIPES $(30.2 \mathrm{~g})$ and Difco agar $(18.0 \mathrm{~g})$. The $\mathrm{pH}$ of the medium was adjusted to 6.8 with the addition of 50 percent $(\mathrm{w} / \mathrm{w})$ sodium hydroxide $(\mathrm{NaOH})$ solution and autoclaved it. Cooled CAS dye was added to the glass wall with gentle agitation to achieve mixing without the formation of foam. The $20 \mathrm{ml}$ of CAS agar dye was added to each plate and stored in a refrigerator $\left(4^{\circ} \mathrm{C}\right)$ for $24 \mathrm{~h}$ before use. The bacterial strains PaRS $(10 \mu \mathrm{l})$ grown overnight were spotted on CAS plates and incubated at $25 \pm 2^{\circ} \mathrm{C}$ for $48 \mathrm{~h}$. A Yellow to orange colored clear zone around the spotted colony was considered as a positive indication of siderophore production.

The CAS-shuttle assay method (Tank and Saraf, 2010) was used for the quantitative estimation of siderophore. The bacterial strains were grown in Fiss minimal medium at $25 \pm 2^{\circ} \mathrm{C}$ for $48 \mathrm{~h}$. The cell suspension was centrifuged at 2,700 rpm for $15 \mathrm{~min}$, CAS assay solution was added to the culture supernatant. The solution was kept for $15 \mathrm{~min}$ and four repetitions of each strain were taken. The absorbance was done at $630 \mathrm{~nm}$ and measurement as per the below formula:

$$
[(A r--A s) / A r] 100=\% \text { siderophoreunits }
$$

where, $\mathrm{Ar}=$ absorbance of reference (minimal media + CAS assay solution), As = absorbance of sample (culture supernatant + CAS assay solution).

\section{Qualitative and Quantitative Estimation of HCN}

Whatman No. 1 filter paper was placed on the lid of the Petri plate to detect $\mathrm{HCN}$ production activity and the plates were sterilized. TSA medium amended with glycine $(4.4 \mathrm{~g} / \mathrm{l})$ was sterilized and poured into the sterile plates as per the protocol of Wei et al. (1991). The seven native bacterial strains were streaked on the medium and filter paper placed in each plate was soaked with $2 \mathrm{ml}$ sterile picric acid solution. The plates were sealed with parafilm in order to contain gaseous metabolites produced by the bacterial strains and allowed the chemical reaction with picric acid present in the filter padding. The color change of the filter paper was noted after 5 days at $30^{\circ} \mathrm{C}$ and the $\mathrm{HCN}$ production potential of bacterial strains was assessed as per Wei et al. (1991). On the basis of filter paper color change from yellow to light brown, brown, or reddish-brown was recorded as weak $(+)$, moderate $(++)$ or strong $(+++)$ reaction, respectively.

For quantitatively estimation of $\mathrm{HCN}$ production, the bacterial strains were grown in the broth contained flask and the medium composition was the same except agar-agar. The filter paper strips $(10 \times 0.5 \mathrm{~cm})$ were soaked in picrate solution and kept hanging position near to neck of the flask. It was incubated at $30^{\circ} \mathrm{C}$ in a rotary shaker and color change was observed after 4 days. The color was eluted by placing the changed filter paper in a test tube containing $10 \mathrm{ml}$ of distilled water, and its absorbance was read by the spectrophotometer at $625 \mathrm{~nm}$. Five repetitions of each treatment were made.

\section{IAA Production}

The native Pseudomonas bacterial strains were inoculated into the pre-sterilized SIM agar slants. The tubes were incubated for $48 \mathrm{~h}$ at room temperature $\left(25 \pm 2^{\circ} \mathrm{C}\right)$. After incubation, 10 drops of Kovac's reagent were added to each tube. The production of red color was considered as positive for indole production.

\section{P-Solubilization}

The bacterial strains were tested for their ability to solubilize insoluble inorganic phosphate on Pikovskaya's agar by adding the overnight grown culture. The plates were incubated for $48 \mathrm{hrs}$ at room temperature. The diameter of the solubilization zone was measured and expressed in millimeters. 


\section{SA}

The quantitative analysis of the SA was done using the method of Meyer et al. (1992). The purple iron-SA complex, developed in the aqueous phase was measured at $527 \mathrm{~nm}$ using a spectrophotometer. A standard curve was prepared with SA dissolved in the succinate medium. The quantity of SA in the culture filtrate was expressed as $\mathrm{mg} / \mathrm{ml}$ (Meyer et al., 1992). Five repetitions of each treatment were made.

\section{Enzymes}

Pseudomonas cell suspension was grown at $28^{\circ} \mathrm{C}$ for $96 \mathrm{~h}$ and mixed in a rotary shaker containing $50 \mathrm{ml}$ of chitin-peptone medium as per Lim et al. (1991). The centrifuged cell suspension supernatant was used as an enzyme source. The reaction mixture was incubated at $50^{\circ} \mathrm{C}$ for $4 \mathrm{~h}$ in a water bath. Chitinase activity was measured by the method Nelson (1944). A unit of chitinase was considered as $1 \mathrm{nmol}$ of GlcNAc released per minute per $\mathrm{mg}$ of protein. The primary procedure followed in chitinase enzyme estimation, the same procedure repeated up to supernatant preparation except growing medium as peptone medium containing laminarin as per Lim et al. (1991). The reaction mixture was incubated at $40^{\circ} \mathrm{C}$ for $2 \mathrm{~h}$ in a water bath and $\beta$-1,3-glucanase activity was measured as $1 \mathrm{nmol}$ of glucose released per minute per $\mathrm{mg}$ of protein. The protein content for both the enzymes was determined as per Bradford (1976). Five repetitions of each treatment were made.

\section{RESULTS}

\section{In vitro Evaluation}

Antifungal and antibacterial properties of bacterial strains were evaluated by dual culture and paper disc methods under in vitro conditions. The PaRS strain recorded minimum mycelial growth $(3.37,3.53,3.47,3.40,2.80,2.47,2.63$, and $2.47 \mathrm{~cm})$ against fungal pathogens and the maximum growth inhibition zone $(20.6,23.67$, and 16.67) in the case of bacterial pathogens, as shown in Table 2. The PaNS and PfNC were also effective to manage mycelia growth after PaRS in the case of bacterial pathogens. PaNS and PaWP were effective against $P$. grisea, C. falcatum, $P$. dermatum, and M. phaseolina while PaNS and PaWS in the rest of the fungal pathogens as mentioned in Table 2.

\section{PGPR and Colonization Activity of PaRS Roll Towel Paper Method}

All the doses of seed treatments (ST) with PaRS proved significantly superior over the control for seed germination. Among these, ST @ 6 g/kg seed was significantly superior over the rest and gave maximum germination (79.78\%). The next best dose was @ $4 \mathrm{~g} / \mathrm{kg}$ (62.89\%). The lowest germination was recorded in untreated seeds i.e., the control (41.56\%) (Table 3). Shoot and root length were significantly more in all the doses of ST tested as compared to control. The significantly larger shoot $(7.94 \mathrm{~cm})$ and root $(2.59 \mathrm{~cm})$ length were recorded in ST @ 6 $\mathrm{g} / \mathrm{kg}$ than the other treatments. The next best treatment was ST @ $4 \mathrm{~g} / \mathrm{kg}$. The lowest shoot and root lengths were recorded in the untreated control (Table 3). All the doses of seed treatment of PaRS produced a significantly higher shoot and root weight as compared to control. Among these, significantly higher shoot $(4.22 \mathrm{mg})$ and root $(1.72 \mathrm{mg})$ weights were recorded in ST @ 6 $\mathrm{g} / \mathrm{kg}$ than the rest of the doses. The next best dose was ST @ $4 \mathrm{~g} / \mathrm{kg}$. The minimum shoot $(1.81 \mathrm{~g})$ and root $(0.49 \mathrm{~g})$ weight was recorded in the control (Table 3 ). The vigor index was significantly higher in all the doses of seed treatments with PaRS as compared to control. Among these, seed treated @ $6 \mathrm{~g} / \mathrm{kg}$ was significantly (838.97) superior as compared to other doses. The next best dose was $4 \mathrm{~g} / \mathrm{kg}$ (458.89) followed by $2 \mathrm{~g} / \mathrm{kg}$ (210.72). The lowest vigor index was recorded in the control (125.85) (Table 3). PaRS colonization was maximum ST at $6 \mathrm{~g} / \mathrm{kg}$ in shoot $\left(6.72 \times 10^{4} \mathrm{cfu} / \mathrm{g}\right)$ and $\operatorname{root}\left(4.83 \times 10^{4} \mathrm{cfu} / \mathrm{g}\right)$. The next best dose was $4 \mathrm{~g} / \mathrm{kg}$. The least PaRS colonization was recorded in $2 \mathrm{~g} / \mathrm{kg}$ seed treatment. There was no bacterial colonization in the control (Table 3).

Thus, seed bacterization with $P$. aeruginosa @ $6 \mathrm{~g} / \mathrm{kg}$ seed proved better for germination and plant height. Further, field confirmations of the results are required for practical utility and feasibility. This can be suggested to the farmers for cost-effective and eco-friendly management of finger millet blast.

\section{Pot Study}

An experiment was conducted to evaluate plant growthpromoting activity of PaRS and results are mentioned in Table 4. The percent germination was observed in ST @ 2, 4, and 6 $\mathrm{g} / \mathrm{kg}$ and at $70 \%$ in control. A significantly higher plant height was recorded in ST at $6 \mathrm{~g} / \mathrm{kg}$ at 15-60 days after transplanting $(52.07-72.36 \mathrm{~cm})$ as compared to other treatments. The next best treatment was ST @ $4 \mathrm{~g} / \mathrm{kg}(47.47-65.20 \mathrm{~cm})$ (Table 4). The minimum plant height was recorded in the untreated control $(29.01-45.60 \mathrm{~cm})$. Seed treatment @ $6 \mathrm{~g} / \mathrm{kg}$ was significantly superior in producing a greater number of leaves (8.68-20.27) than the rest of the doses at 15-60 days after transplanting. The next best treatment was ST @ $4 \mathrm{~g} / \mathrm{kg}$ (7.87-17.07). The least number of leaves was recorded in the control (4.63-11.20) (Table 4).

\section{Colonization}

The ability of PaRS for colonization was studied during the pot study and results are mentioned in Table 4. The bacterial colonization in the rhizosphere was significantly higher in all the treatments as compared to the control. Among these, the seed treatment @6 g/kg seeds proved superior at $15\left(5.06 \times 10^{6}\right.$ $\mathrm{cfu} / \mathrm{g}), 30\left(6.67 \times 10^{6} \mathrm{cfu} / \mathrm{g}\right), 45\left(8.00 \times 10^{6} \mathrm{cfu} / \mathrm{g}\right)$ and $60(7.06$ $\left.\times 10^{6} \mathrm{cfu} / \mathrm{g}\right)$ days after transplanting having significantly higher bacterial counts as compared to the rest (Table 4). The next best in order of merit was seed treatment @ $4 \mathrm{~g} / \mathrm{kg}$ while $2 \mathrm{~g} / \mathrm{kg}$ was comparatively less effective. This showed that seed treatment @ PaRS $6 \mathrm{~g} / \mathrm{kg}$ was better for increasing bacterial rhizosphere colonization. The seed treatment of PaRS recorded higher plant height, the greatest number of leaves, and largest colonization up to 60 days (Table 4).

\section{Biochemical Characterization}

The biochemical properties i.e., indole acetic acid, hydrogen cyanide, siderophore, and P-solubilizing of seven Pseudomonas spp. were studied and results were interpreted in Table 5. 
TABLE 2 | Fungal mycelial growth and bacterial inhibition zone by Pseudomonas isolates.

\begin{tabular}{|c|c|c|c|c|c|c|c|c|c|c|c|c|}
\hline Sr. No. & $\begin{array}{l}\text { Pseudomonas } \\
\text { isolates }\end{array}$ & P. grisea & $\begin{array}{l}\text { C. } \\
\text { falcatum }\end{array}$ & $\begin{array}{l}P . \\
\text { aphanidermatum }\end{array}$ & $\begin{array}{l}P . \\
\text { anacardii }\end{array}$ & $\begin{array}{l}\text { L. } \\
\text { theobromae }\end{array}$ & $\begin{array}{l}\text { M. } \\
\text { phaseolina }\end{array}$ & $\begin{array}{l}\boldsymbol{F} \\
\text { moniliformae }\end{array}$ & S. rolfsii & $X C M$ & xoo & XAC \\
\hline 1 & PaWP & $3.73^{\text {de }}$ & $3.57^{d}$ & $3.73^{\mathrm{c}}$ & $4.30^{\mathrm{bc}}$ & $3.69^{b c}$ & $2.7^{\text {cde }}$ & $4.07^{b}$ & $2.7^{\mathrm{de}}$ & $15^{d}$ & $21^{c}$ & $14.67^{c}$ \\
\hline 2 & PfWN & $4.37^{\mathrm{bc}}$ & $4.7^{b}$ & $3.80^{c}$ & $4.57^{b c}$ & $4.00^{b}$ & $3.6^{b}$ & $3.53^{b c}$ & $3.73^{b}$ & $11^{e}$ & $17^{d}$ & $9.33^{e}$ \\
\hline 3 & PaWS & $4.07^{\mathrm{bcd}}$ & $4.2^{b c}$ & $4.40^{b}$ & $4.00^{c}$ & $3.07^{\text {de }}$ & $2.83^{\mathrm{cd}}$ & $2.5^{\mathrm{e}}$ & $2.63^{\mathrm{e}}$ & $10.67^{e}$ & $11.00^{f}$ & $10.67^{d}$ \\
\hline 4 & PfRB & $4.53^{b}$ & $4.53^{b c}$ & $3.90^{b c}$ & $4.80^{b}$ & $3.63^{b c d}$ & $3.1^{b c}$ & $3.1^{\mathrm{cd}}$ & $3.1^{c d}$ & $10.33^{\mathrm{e}}$ & $15.00^{e}$ & $9.00^{\mathrm{e}}$ \\
\hline 5 & PaRS & $2.7^{f}$ & $2.8^{\mathrm{e}}$ & $3.03^{d}$ & $3.13^{d}$ & $2.37^{f}$ & $2.2^{\mathrm{e}}$ & $2.3^{e}$ & $2.1^{f}$ & $23.33^{a}$ & $26.00^{a}$ & $18.67^{a}$ \\
\hline 6 & PaNS & $3.37^{e}$ & $3.53^{d}$ & $3.47^{\mathrm{cd}}$ & $3.40^{d}$ & $2.80^{e f}$ & $2.47^{\text {de }}$ & $2.63^{\text {de }}$ & $2.47^{\mathrm{ef}}$ & $20.67^{b}$ & $23.67^{b}$ & $16.67^{b}$ \\
\hline 7 & PfNC & $3.87^{\text {cde }}$ & $3.97^{\mathrm{cd}}$ & $4.00^{b c}$ & $4.07^{c}$ & $3.38^{\mathrm{cd}}$ & $3.17^{b c}$ & $3.17^{\mathrm{cd}}$ & $3.17^{c}$ & $17^{c}$ & $23.00^{b}$ & $17.33^{b}$ \\
\hline 8 & Control & $8.93^{a}$ & $8.77^{a}$ & $8.63^{a}$ & $8.70^{a}$ & $9.00^{a}$ & $9.00^{\mathrm{a}}$ & $9.00^{a}$ & $9.00^{a}$ & $0^{f}$ & $0^{g}$ & $0^{f}$ \\
\hline
\end{tabular}

Data are mean of three replications.

Means followed by the same letter in a column are not significantly different $(P=0.05)$ by DMRT.

TABLE 3 | Effect of seed bacterization by P. aeruginosa on plant growth promoting activity of Finger millet (Roll Towel Paper Method).

\begin{tabular}{|c|c|c|c|c|c|c|c|c|c|}
\hline \multirow[t]{2}{*}{ Sr. no. } & \multirow{2}{*}{$\begin{array}{l}\text { Seed } \\
\text { treatment }\end{array}$} & \multirow{2}{*}{$\begin{array}{l}\text { Germination } \\
(\%)\end{array}$} & \multirow{2}{*}{$\begin{array}{l}\text { Shoot length } \\
(\mathrm{cm})\end{array}$} & \multirow{2}{*}{$\begin{array}{l}\text { Root length } \\
\text { (cm) }\end{array}$} & \multirow{2}{*}{$\begin{array}{l}\text { Shoot } \\
\text { weight (g) }\end{array}$} & \multirow{2}{*}{$\begin{array}{l}\text { Root weight } \\
\text { (g) }\end{array}$} & \multirow[t]{2}{*}{ Vigour index } & \multicolumn{2}{|c|}{ PaRS colonization } \\
\hline & & & & & & & & $\begin{array}{l}\text { Shoot } \\
\left(\times 10^{4} \mathrm{cfu} / \mathrm{g}\right)\end{array}$ & Root $\left(\times 10^{4} \mathrm{cfu} / \mathrm{g}\right)$ \\
\hline 1 & $2 \mathrm{~g} / \mathrm{kg}$ & $50.66^{c}$ & $3.01^{\mathrm{C}}$ & $1.15^{\mathrm{c}}$ & $2.82^{\mathrm{C}}$ & $0.9^{c}$ & $210.72^{\mathrm{C}}$ & $3.56^{\mathrm{c}}$ & $2.28^{\mathrm{C}}$ \\
\hline 2 & $4 \mathrm{~g} / \mathrm{kg}$ & $62.89^{b}$ & $5.49^{b}$ & $1.74^{\mathrm{b}}$ & $3.43^{b}$ & $1.44^{\mathrm{b}}$ & $455.59^{b}$ & $5.44^{\mathrm{b}}$ & $3.94^{\mathrm{b}}$ \\
\hline 3 & $6 \mathrm{~g} / \mathrm{kg}$ & $79.78^{a}$ & $7.94^{a}$ & $2.59^{a}$ & $4.22^{\mathrm{a}}$ & $1.72^{\mathrm{a}}$ & $838.97^{a}$ & $6.72^{\mathrm{a}}$ & $4.83^{\mathrm{a}}$ \\
\hline
\end{tabular}

Data are mean of five replications.

Means followed by the same letter in a column are not significantly different $(P=0.05)$ by DMRT.

PaRS showed high siderophore fluorescence while PfRB, PaNS, and PfNC recorded medium siderophore fluorescence (Table 5). The weak siderophore fluorescence was observed in PaWP, PfWN, and PaWS strain (Table 5). The maximum siderophore production was recorded in PaRS (12.20 \pm 0.08$)$ followed by PaNS and PfNC $(11.86 \pm 0.16$ and $10.06 \pm 0.07)$ as mentioned in Table 6 . The minimum siderophore production was recorded in PaWN (5.38 \pm 0.06$)$.

Among the 7 strains of Pseudomonas spp. tested for the HCN production, the highest production of $\mathrm{HCN}$ was recorded in isolate PaRS $(0.084 \pm 0.003)$ followed by PaNS $(0.066 \pm 0.003)$. The next best isolate for HCN production was PaWN, PaNC, PaWP, and PfRB. The lowest production was found in PaWS (Table 6).

All the seven native strain of Pseudomonas were positive to IAA production. PaRS showed high siderophore fluorescence while PfRB, PaNS, and PfNC recorded medium siderophore fluorescence (Table 5). The weak siderophore fluorescence was observed in PaWP, PfWN, and PaWS strain (Table 5). Strong HCN production was observed in PaNS and PaRS while moderate in PaWP, PaWS, and PfNC. The highest P-solubilizing zone $(22 \mathrm{~mm})$ was recorded in PaRS followed by PaNS $(20 \mathrm{~mm})$ as mentioned in Table 4 . The P-solubilizing zone in PfWN, PaWS, PaWP, and PfRB was $18,17,15$, and $14 \mathrm{~mm}$, respectively. The lowest inhibition was recorded in the PfNC $(10 \mathrm{~mm})$ as mentioned in Table 5.
The SA production was found to be the maximum in PaRS $(12.68 \pm 0.36)$ followed by the PaNS $(10.84 \pm 0.39)$ and PfNC $(10.24 \pm 0.24)$ isolate (Table 6). The PaWP recorded the lowest $(1.68 \pm 0.07)$ SA production.

The lytic enzyme production supported antagonism, which is the ideal character of an effective bioagent for plant diseases management. The PaRS (76.24 \pm 0.35 and $132.36 \pm 0.31)$ recorded the highest activity of chitinase and b-1,3-glucanase enzymes followed by PaNS (54.38 \pm 0.29 and $116.20 \pm 0.26$ ), respectively. The lowest chitinase activity was found in PaWN $(12.36 \pm 0.21)$, while PaWP $(28.18 \pm 0.06)$ isolate in b-1, 3glucanase (Table 6).

\section{DISCUSSION}

\section{In vitro Evaluation}

The efficiency of different strains of $P$. fluorescens and $P$. aeruginosa were also reported significant against $P$. oryzae (Gnanamanickam and Mew, 1992), S. rolfsii and Xanthomonas campestris pv. malvacearum (Bhowmik et al., 2002), F. moniliformae (Sharma et al., 2007), C. falcatum (Sangeetha et al., 2009), P. aphanidermatum (Muthukumar et al., 2010), R. solani and M. grisea (Reddy et al., 2010), L. theobromae (Nath, 2010), and P. anacardii (Patil, 2012) earlier. The native strains became most potent for the reduction of pathogen growth confirmed as per the results of Manjula et al. (2004), Sen et al. (2006), Razeena and Rasheed (2007), Sivakumar (2007), 


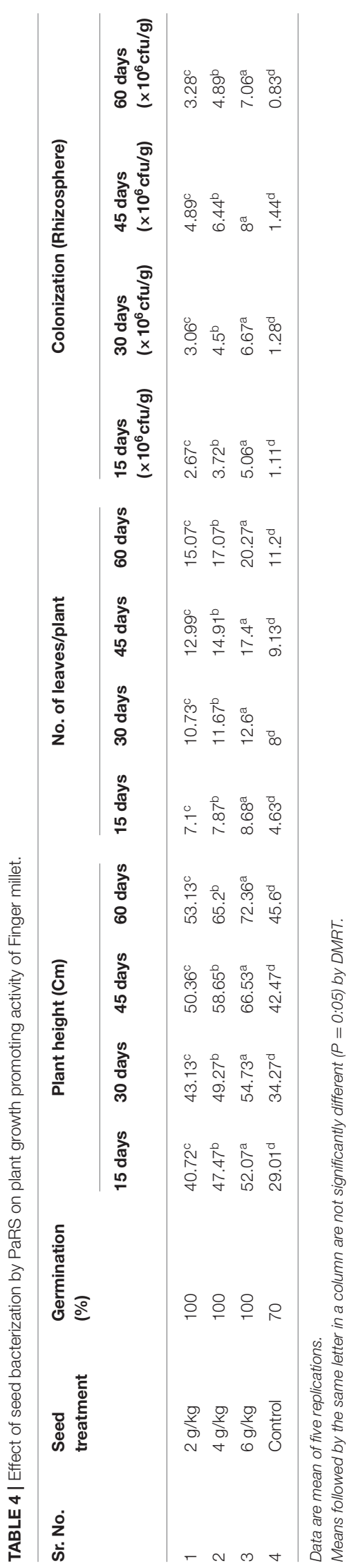

and Vishwanathan and Samiyappan (2007). Reported that 14 bacterial isolates inhibit the mycelia growth of $M$. phaseolina due to $\mathrm{HCN}$, chitinase, b-1,3-glucanase, and siderophore production. An antagonist exhibits direct and indirect mechanisms to inhibit pathogen growth. The production of volatile and non-volatile compounds along with lytic enzymes reduced the vegetative growth of pathogens. The present results are more or less similar to Arora and Verma (2017), who observed that fluorescent Pseudomonas spp. Inhibited the mycelia growth of P. capsici and $R$. solani. Yasmin et al. (2017) evaluated $P$. aeruginosa against BLB rice pathogen strains under in vitro conditions because of lytic enzymes and secondary metabolites production. In the present investigation, PaRS proved as a potential bioagent against important fungal as well as bacterial pathogens.

\section{PGPR and Colonization}

The results of the experiments are quite confirmative with the results of Ramanathan et al. (2002) who revealed that all the strains of $P$. fluorescens promoted plant growth. Ramamoorthy and Samiyappan (2002) supported that seed bacterization with $P$. fluorescens isolate $P f-1$ effectively increased plant vigor and produced the maximum amount of IAA in the culture medium. The increase in plant biomass in respect to germination, plant height, root and shoot weight, and vigor index may be due to higher water and nutrient uptake, phytohormone production i.e., gibberellic acid, indole acetic acid, and siderophore production by PaRS. The antagonist inoculum dose and its delivery system determine and significantly influence their population in the crop rhizosphere (Fischer et al., 2010). PaRS might have also contained the enzyme 1-aminocyclopropane-1-carboxylate (ACC) deaminase, a hydrolase of ACC (the precursor of ethylene in the plant), and thus, in this way reduce the level of ethylene during plant development. PaRS could also increase $\mathrm{K}, \mathrm{Zn}$, and $\mathrm{Mn}$ uptake by the above plant parts. It might also be produced organic acids involved in phosphorus solubilization or the fixation of atmospheric $\mathrm{N}_{2}$ (Smolin and Shabaev, 1992).

The results corroborate with, Bergsma-Vlami et al. (2005) who recorded the significant effect of plant species on the population densities of fluorescent Pseudomonas spp. The dynamics of bacteria population are a complex phenotype affected by many different traits and environmental factors. These are motility, synthesis of the $\mathrm{O}$-antigen of lipopolysaccharide and cellulose, thiamine production, amino acid synthesis biotin production, and an isoflavanoid-inducible efflux pump.

Pseudomonas spp. synthesizes osmolytes to protect themselves against fluctuations in osmotic conditions and accumulate to higher levels to alleviate stress effects. The accumulated osmolytes enhance the stability of proteins and membranes under waterlimiting environments. PaRS might have produced proline, free amino acid, sugars, and extracellular polysaccharides (EPS) under stress conditions than under non-stressed conditions, indicating the role of these metabolites in stress tolerance to maintain PaRS population. However, the concentration of protein should be reduced significantly under stress indicating the degeneracy under stress conditions. Under stress, proteins are used for polysaccharide production. PaRS might have EPS under stress conditions, EPS produced by bacterial cells forms as an 
TABLE 5 | Biochemical properties of native isolates of Pseudomonas spp.

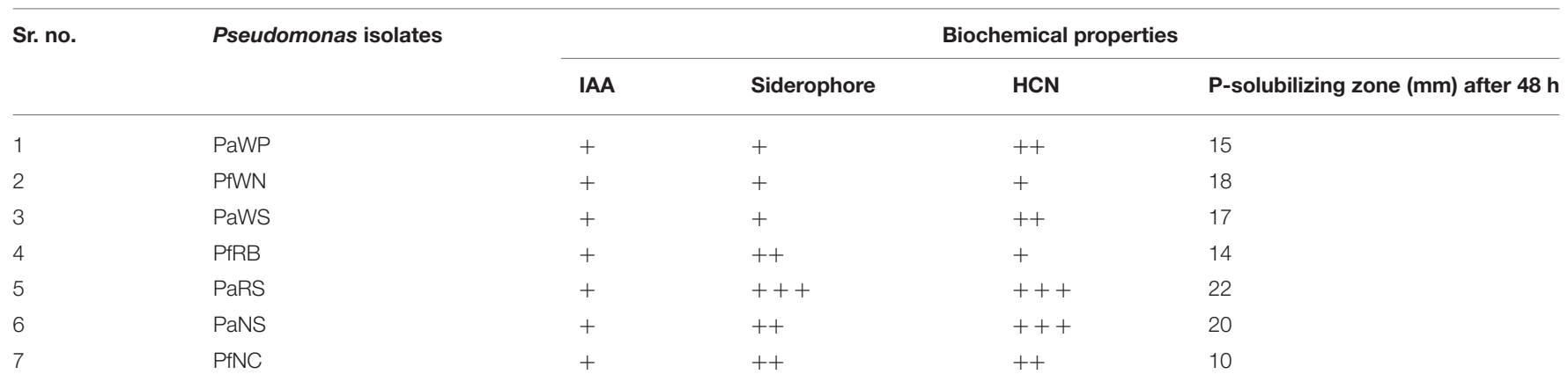

IAA: +, Presence; -, Absent. Siderophore fluorescence: +++, High; ++, Medium; +, Weak. HCN production: -, No HCN; +, Weak; ++, Moderate; +++, Strong.

TABLE 6 | Secondary metabolites and enzymes productions by native isolates of Pseudomonas spp.

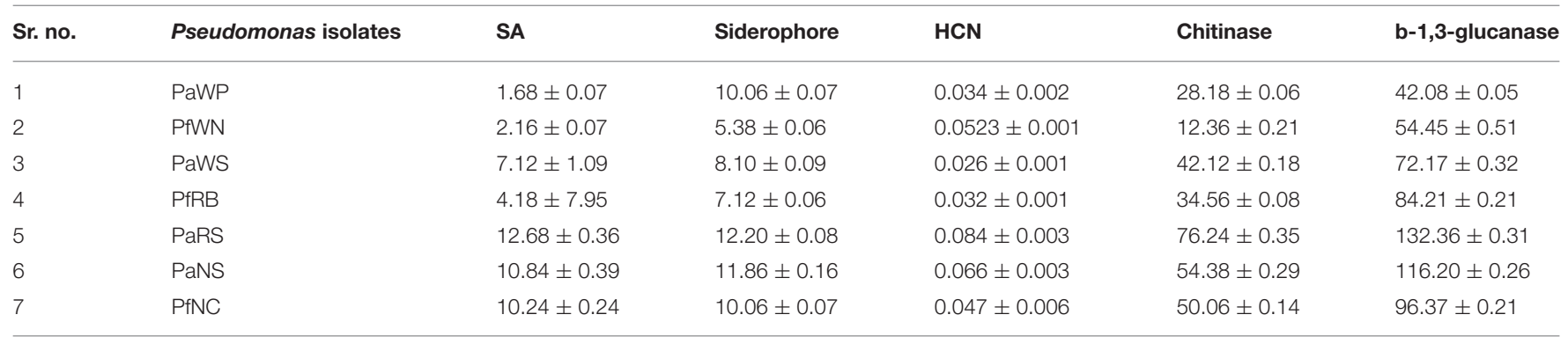

Data are represented by the mean of five replicates \pm standard deviation.

organo-mineral sheath around the colonies that creates a microenvironment that decreases the water potential decline. The level of glutamate in PaRS might have increased in response to osmotic stress conditions. The desiccation-tolerant cells also accumulate high levels of disaccharides such as trehalose, sorbitol, fructose, glucose, and sucrose, which protect cellular enzymes by replacing water around macromolecules and also stabilize cell membranes during desiccation (Sandhya et al., 2010).

PaRS population increased after 15 and 30 days, it might be due to that above-discussed characteristics that may be possessed in PaRS during rhizospheric osmotic stress conditions. The Psolubilisation and IAA production capacity of PaRS is better than in the others, hence helping to promote growth. The higher HCN production might be reducing the pathogen infection which helps to maintain the plant health as compared to rest. The higher siderophore production in PaRS probably helps the survivability and colonization. The decreased colonization after 45 and 60 days might be due to the optimum availability of protein in the PaRS and hence there is no conversion of protein in EPS.

\section{Biochemical Characterization}

The quantitatively $\mathrm{HCN}$ production results are similar to the result of Goswami et al. (2013), Reetha et al. (2014), Rijavec and Lapanje (2016) and Abd El-Rahman et al. (2019) under in vitro conditions.

The six isolates of bacteria (Pseudomonas japonica strain NBRC 103040, Bacillus megaterium strain CtST3.5, Pseudomonas sp. strain Gamma-81, P. tolaasii strain ATCC 33618, $P$. chlororaphis strain Lzh-T5, and P. mosselii strain CV25) inhibit the growth of Agrobacterium tumefaciens as reported by Abd ElRahman et al. (2019). Reetha et al. (2014) found a similar result; they isolated Pseudomonas and Bacillus from the sunflower rhizosphere. The inhibition of Macrophomina phaseolina was found under in vitro conditions due to $\mathrm{HCN}$ production. Goswami et al. (2013) isolated Pseudomonas spp. from marine water and recorded IAA, HCN, phosphate solubilization, and siderophore production which increased chickpea and green gram growth. Rijavec and Lapanje (2016) found that Fusarium moniliforme EXF1, F.graminearum EXF2, Pseudomonas syringae pv. syringae z1, P.syringae pv. coronafaciens z1238, Erwinia carotovora pv. carotovora $\mathrm{z87}$, and Xanthomonas campestris pv. campestris recorded growth inhibition in the presence of HCN.

The quantitative siderophore production results are similar to the results of Goswami et al. (2013), Arora and Verma (2017), and Nithyapriya et al. (2021).

The siderophore results also respond to the finding by Arora and Verma (2017) that 23 bacteria including Pseudomonas, Rhizobium, Enterobacter, Chronobacter, Kosakonia, Beijerinckia, and Pantoea spp. genus produced the siderophore at different levels. The Bacillus sp. LSB2 produced siderophore which helped to increase plant growth and other biochemical parameters of sesame as recorded by Nithyapriya et al. (2021).

The results are less or more similar to Megha et al. (2007) who studied the quantitative estimation of 52 
fluorescent Pseudomonas for GA, IAA, protease, and phosphate solubilization similarly to the present study. Meera and Balabaskar (2012) studied Gram staining, gelatin, liquefaction, catalase and oxidase test, starch hydrolysis, siderophore, and HCN production. Umamaheswari et al. (2008) detected activity of IAA, SA, HCN, and siderophore from $P$. fluorescens (PfCIAH-196) with the same results as obtained in the present study.

\section{Statistical Analysis}

The biochemical experiments were performed in five repetitions and the data is represented as mean_standard deviation (SD). The data were analyzed by One Way Analysis of Variance (ANOVA) and DMRT tests. The significant differences in the means were analyzed based on the DMRT test $(p<0.05)$.

\section{REFERENCES}

Abd El-Rahman, A. F., Shaheen, H. A., Abd El-Aziz, R. M., and Ibrahim, D. S. S. (2019). Influence of hydrogen cyanide-producing rhizobacteria in controlling the crown gall and root-knot nematode, Meloidogyne incognita. Egypt J. Biol. Pest. Control 29:41. doi: 10.1186/s41938-019-0143-7

Arora, N. K., and Verma, M. (2017). Modified microplate method for rapid and efficient estimation of siderophore produced by bacteria. Biotechnology 7:381. doi: 10.1007/s13205-017-1008-y

Baki, A. A., and Anderson, J. D. (1973). Vigour determination in soybean by multiple criteria. Crop Protect. 13, 630-632. doi: 10.2135/cropsci1973.0011183X001300060013x

Bergsma-Vlami, M., Prins, M. E., and Raaijmakers, J. M. (2005). Influence of plant species on population dynamics, genotypic diversity and antibiotic production in the rhizosphere by indigenous Pseudomonas spp. FEMS Microbiol. Ecol. 52, 59-69. doi: 10.1016/j.femsec.2004.10.007

Bhowmik, B., Singh, R. P., Jayaraman, J., and Verma, J. P. (2002). Population dynamics of cotton endophytic Pseudomonas, their antagonism and protective action against the major pathogens of cotton. Indian Phytopath. 55, 124-132. Available online at: http://epubs.icar.org.in/ejournal/index.php/IPPJ/article/ view/18679

Bradford, M. M. (1976). A rapid and sensitive method for the quantification of microgram quantities of protein utilizing the principle of proteindye binding. Anal. Biochem. 72, 248-254. doi: 10.1016/0003-2697(76)9 0527-3

Dennis, C., and Webster, J. (1971). Antagonistic Properties of species groups of Trichoderma III hyphal interaction. Trans. Brt. Mycol. Soc. 57, 363-369. doi: 10.1016/S0007-1536(71)80050-5

Durairaj, K., Velmurugan, P., Park, J., Chang, W., Park, Y., Senthilkumar, P. et al. (2017). Potential for plant biocontrol activity of isolated Pseudomonas aeruginosa and Bacillus stratosphericus strains against bacterial pathogens acting through both induced plant resistance and direct antagonism. FEMS Microbiol. Lett. 364:fnx225. doi: 10.1093/femsle/fnx225

Fischer, S. E., Jofre, E. C., Cordero, P. V., Manero, F. J. G., and Mori, G. B. (2010). Survival of native Pseudomonas in soil and wheat rhizosphere and antagonist activity against plant pathogenic fungi. Antonie van Leeuwenhoek 97, 241-251. doi: 10.1007/s10482-009-9405-9

Gnanamanickam, S., and Mew, T. W. (1992). Biological control of blast disease of rice (Oryza sativa L.) with antagonistic bacteria and its mediation by a Pseudomonas antibiotic. Ann. Phytopath. Soc. Japan 58, 380-385. doi: 10.3186/jjphytopath. 58.380

Goswami, D.,Vaghela, H., Parmar, S., Dhandhukia, P., Thakker, J. N. (2013). Plant growth promoting potentials of Pseudomonas spp. strain OG isolated from marine water. J. Plant Interac. 8, 281-290. doi: 10.1080/17429145.2013.768360

Iftikhar, Y., Sajid, A., Shakeel, Q., Ahmad, Z., and Haq, Z. (2020). "Biological Antagonism: safe and sustainable way to manage plant diseases,"

\section{DATA AVAILABILITY STATEMENT}

The original contributions presented in the study are included in the article/supplementary material, further inquiries can be directed to the corresponding author.

\section{AUTHOR CONTRIBUTIONS}

AS and RW contributed equally with experiment conduction. All authors contributed to the article and approved the submitted version.

\section{ACKNOWLEDGMENTS}

The authors are highly thankful to Dr. R. M. Shelake for enzyme and secondary metabolite analysis.

in Plant Disease Management Strategies for Sustainable Agriculture Through Traditional and Modern Approaches (Berlin: Springer), 83-109. doi: 10.1007/978-3-030-35955-3_5

Islam, A., Nain, Z., Alam, M., Banu, A., and Islam, R. (2018). In vitro study of biocontrol potential of rhizospheric Pseudomonas aeruginosa against Fusarium oxysporum f. sp. cucumerinum. Egypt. J. Biol. Pest Control 28:90. doi: 10.1186/s41938-018-0097-1

ISTA (1985). International rules for seed testing on the rice. Ind. J. Pl. Prot. 6, 30-32.

Kishore, G. K., Pande, S., and Podile, A. R. (2005a). Biological control of collar rot disease with broadspectrum antifungal bacteria associated with groundnut. Can. J. Microbiol. 51, 123-132. doi: 10.1139/w04-119

Kishore, G. K., Pande, S., Rao, J., N., and Podile, A. R. (2005b). Pseudomonas aeruginosa inhibits the plant cell wall degrading enzymes of Sclerotium rolfsii and reduces the severity of groundnut stem rot. Eur J. Plant Pathol. 113, 315-320. doi: 10.1007/s10658-005-0295-z

Kumar, A. (2009). Biocontrol of plant disease: need to tap the options. J. Arid Legumes. 6, 20-29. Available online at: https://www.researchgate.net/ publication/278676073_Biocontrol_of_plant_diseases_Need_to_tap_the_ options

Lim, H., Kim, Y., and Kim, S. (1991). Pseudomonas stutzeri YLP-1 genetic transformation and antifungal mechanism against Fusarium solani, an agent of plant root rot. Appl. Environ. Microbiol. 57, 510-516. doi: 10.1128/aem.57.2.510-516.1991

Manjula, K., Kishore, G. K., Girish, A. G., and Singh, S. D. (2004). Combined application of Pseudomonas fluorescens and Trichoderma viride has an improved biocontrol activity against stem rot in Groundnut. Plant Pathol. J. 20, 75-80. doi: 10.5423/PPJ.2004.20.1.075

Meera, T., and Balabaskar, P. (2012). Isolation and characterization of Pseudomonas fluorescens from rice fields. Int. J. Food Agric. Vet. Sci. 2, 113-120. Available online at: https://www.cibtech.org/J-FOOD-AGRI-VETERINARYSCIENCES/PUBLICATIONS/2012/Vol\%202\%20No\%201/17-012\%20JFAV $\% 20 \mathrm{~T} \% 20$ Meera.pdf

Megha, Y. J., Alagawadi, A. R., and Krishnaraj, P. U. (2007). Multiple beneficial functions of fluorescent Pseudomonads of Western Ghats of Uttara Kannada districts. Karnataka J. Agric. Sci. 20, 305-309. Available online at: https://www. researchgate.net/publication/228645910_Multiple_Beneficial_Functions_of_ Fluorescent_Pseudomonads_of_Western_Ghats_of_Uttara_Kannada_District Meyer, J. M., Azelvandre, P., and Georges, C. (1992). Iron metabolism in Pseudomonas: salicylic acid, a siderophore of Pseudomonas?uorescens CHAO. Biofactors 4, 23-27.

Morales-Cedeño, L. R., Carmen Orozco-Mosqueda, M., Loeza-Lara, P. D., ParraCota, F. I., Santos-Villalobos, S., and Santoyo, G. (2021). Plant growthpromoting bacterial endophytes as biocontrol agents of pre- and postharvest diseases: fundamentals, methods of application and future perspectives. Microbiol. Res. 242:126612. doi: 10.1016/j.micres.2020.126612 
Muniroha, M. S., Nusaibaha, S. A., Vadamalaia, G., and Siddiqueb, Y. (2019). Proficiency of biocontrol agents as plant growth promoters and hydrolytic enzyme producers in Ganoderma boninense infected oil palm seedlings. Curr. Plant Biol. 20:100116. doi: 10.1016/j.cpb.2019.100116

Muthukumar, A., Bhaskaran, R., and Sanjeevkumar, K. (2010). Efficacy of endophytic Pseudomonas fluorescens (Trevisan) Migula against chilli dampingoff. J. Biopest. 3, 105-109. Available online at: www.jbiopest.com/users/LW8/ efiles/Muthukumar.pdf

Nath, K. (2010). Molecular characterization, epidemiology and management of banana fruit rot caused by Lasiodiplodia theobromae under South Gujarat conditions (Ph. D. thesis). Navsari Agricultural University, Navsari.

Nelson, N. (1944). A photometric adaptation of the Somogey method for the determination of glucose. J. Biol. Chem. 152, 375-380. doi: 10.1016/S0021-9258(18)71980-7

Nithyapriya, S., Lalitha, S., Sayyed, R. Z., Reddy, M. S., Dailin, D. J., El Enshasy, H. A., et al. (2021). Production, purification, and characterization of bacillibactin siderophore of Bacillus subtilis and its application for improvement in plant growth and oil content in sesame. Sustainability 13:5394. doi: 10.3390/su13105394

Papavizas, G. C., and Davey, C. B. (1960). Rhizoctonia disease of bean as affected by decomposing green plants materials and associated microflora. Phytopathology 50, 516-522.

Patil, V. A. (2012). Investigation on grey leaf blight disease [Pestalotia anacardii] of Mango (Mangifera indica L.) under South Gujarat condition (Ph. D. Kaccha bound thesis). Navsari Agricultural University, Navsari, Gujarat

Ramamoorthy, V.; Raghuchander, T., and Samiyappan, R. (2002). Induction of defense related proteins in tomato roots treated with Pseudomonas fluorescens Pf1 and Fusarium oxysporum f. sp. lycopersici. Plant Soil 239, 55-68. doi: 10.1023/A:1014904815352

Ramanathan, A., Shanmugam, V., Raghuchander, T., and Samiyappan, R. (2002). Induction of systemic resistance in ragi against blast disease by Pseudomonas fluorescens. Ann. Plant Prot. Sci. 20, 313-318.

Razeena, P. M., and Rasheed, A. (2007). Control of seed borne fungi of okra with Pseudomonas fluorescens and aqueous leaf extract of Henna (Lawsonia inermis L.). J. Mycol. Plant Pathol. 37, 485-486.

Reddy, B. P., Rani, J., Reddy, M. S., and Kumar, K. V. K. (2010). In vitro antagonistic potential of Pseudomonas fluorescens isolates and their metabolites against rice sheath blight pathogens, Rhizoctonia solani. Int. J. Appl. Biol. Pharmacol. Technol. 1, 676-679.

Reetha, A. K., Pavani, S. L., and Mohan, S. (2014). Hydrogen cyanide production ability by bacterial antagonist and their antibiotics inhibition potential on Macrophomina phaseolina (Tassi.) Goid. Int. J. Curr. Microbiol. App. Sci. 3, 172-178. Available online at: https://www.ijcmas.com/vol-3-5/A.Karmel \%20Reetha, \%20et\%20al.pdf

Rijavec, T., and Lapanje, A. (2016). Hydrogen cyanide in the rhizosphere: not suppressing plant pathogens, but rather regulating availability of phosphate. Front. Microbiol. 7:1785. doi: 10.3389/fmicb.2016.01785

Sandhya, V., Ali, S. Z., Veenkateswarlu, B., Reddy, G., and Grover, M. (2010). Effect of osmotic stress on plant growth promoting Pseudomonas spp. Arch. Microbiol. 192, 867-876. doi: 10.1007/s00203-010-0613-5

Sangeetha, A., Mohan, S., and Neelamegam, R. (2009). In vitro evaluation of fungal and bacterial antagonists against Colletotrichum. J. Biol. Control. 23, 333-336. Available online at: http://www.i-scholar.in/index.php/jbc/article/view/46052/ 37406

Schwyn, B., and Neilands, J. B. (1987). Universal chemical assay for the detection and determination of siderophore. Anal. Biochem. 160, 47-56. doi: 10.1016/0003-2697(87)90612-9

Sen, S., Acharya, R., and Acharya, K. (2006). In vitro antagonistic effect of fluorescent Pseudomonas BRL-1 against Aspergillus niger. J. Mycopathol. Res. 44, 97-100. Available online at: https://www.researchgate.net/ profile/Surjit-Sen/publication/259479116_In_vitro_antagonistic_effect_ of_Fluorescent_Pseudomonas_BRL-1_against_Aspergillus_niger/links/ 591a0647aca2722d7cfe7a0a/In-vitro-antagonistic-effect-of-FluorescentPseudomonas-BRL-1-against- Aspergillus-niger.pdf

Sharma, K., Saxena, A., Dak, G., Sharma, R., and Agrawal, A. (2007). Isolation and assay of antifungal activity of siderophore producing strain of Pseudomonas aeruginosa. J. Mycol. Pl. Pathol. 37, 251-253.

Shelake, R. M., Waghunde, R. R., and Kim, J. Y. (2019). "Plant-Microbe-Metal (PMM) interactions and strategies for remediating metal ions," in Plant-Metal Interactions, eds S. Srivastava, A. Srivastava, P. Suprasanna (Cham: Springer)
Sivakumar, R. (2007). Efficacy of PGPR against phytopathogenic fungi, J. Agric. Sci. Dig. 45, 22-25.

Smolin, V. Y., and Shabaev, V. P. (1992). Chemical composition of soybean plants inoculated with nodule bacteria and rhizosphere pseudomonads or endomycorrhizal fungi with localized application of nitrogen fertilizer. Agrokhimiya 11, 73-79.

Tank, N., and Saraf, M. (2010). Salinity-resistant plant growth promoting rhizobacteria ameliorates sodium chloride stress on tomato plants. J. Plant Interact. 5, 51-58. doi: 10.1080/174291409031 25848

Thornberry, H. H. (1950). A paper disc method for the quantitative evaluation of fungicides and bactericides. Phytopathology 40, 419-420.

Umamaheswari, C., Sankarligngam, A., and Nallathambi, P. (2008). Mechanisms of action exerted by biocontrol agents against Altenaria alternata causing leaf blight of watermelon. J. Mycol. Plant Pathol. 38, 59-64. Available online at: http://www.connectjournals.com/achivestoc2.php?abstract=92501H_59-64 abs.htm\&\&bookmark=cj-000953\&\&issue_id=01\&\&yaer $=2008$

Verma, P. P., Shelake, R. M., Das, S., Sharma, P., and Kim, J. Y. (2019). "Plant growth-promoting rhizobacteria (PGPR) and fungi (PGPF): potential biological control agents of diseases and pests," in Microbial Interventions in Agriculture and Environment, eds D. Singh, V. Gupta, R. Prabha (Singapore: Springer), 281-311.

Verma, P. P., Shelake, R. M., Sharma, P., Kim, J. Y., Das, S., and Kaur, M. (2020). "Microbes in crop production: formulation and application," in Microbial Diversity, Interventions and Scope, eds S. Sharma, N. Sharma, M. Sharma (Singapore: Springer), 51-73.

Vidhyasekaran, P., Rabindran, R., Muthamilan, M., Nayar, K., Rajappan, K., Subramanian, N., et al. (1997). Development of a powder formulation of Pseudomonas fluorescens for control of rice blast. Plant Pathol. 46, 291-297.

Vishwanathan, R., and Samiyappan, R. (2007). Siderophores and iron nutrition on the Pseudomonas mediated antagonism against Colletotrichum falcatum in sugarcane. Sugar Tech. 9, 57-60. doi: 10.1007/BF02956914

Waghunde, R. R., Shelake, R. M., and Sabalpara, A. N. (2016). Trichoderma: a significant fungus for agriculture and environment. Afr J Agric Res. 11, 1952-1965. doi: 10.5897/AJAR2015.10584

Waghunde, R. R., Shinde, C. U., Pandey, P., and Singh, C. (2021). "Fungal biopesticides for agro-environmental sustainability," in Industrially Important Fungi for Sustainable Development. Fungal Biology, eds A. M. Abdel-Azeem, A. N. Yadav, N. Yadav, Z. Usmani (Cham: Springer).

Wei, G., Kloepper, J. W., and Tuzun, S. (1991). Induction of systemic resistance of cucumber to Colletotrichum orbiculare by selected strains of plant growth promoting rhizobacteria. Phytopathology 81, 1508-1512. doi: 10.1094/Phyto-81-1508

Wong, C. K. F., Dzarifah, Z., Noor Baity, S., and Ganesan, V. (2021). A Consortium of Pseudomonas aeruginosa and Trichoderma harzianum for improving growth and induced biochemical changes in fusarium wilt infected bananas. Trop. Life Sci. Res. 32, 23-45. doi: 10.21315/tlsr2021.32.1.2

Yasmin, S., Hafeez, F. Y., Mirza, M. S., Rasul, M., Arshad, H. M. I., Zubair, M., et al. (2017). Biocontrol of bacterial leaf blight of rice and profiling of secondary metabolites produced by rhizospheric Pseudomonas aeruginosa BRp3. Front. Microbiol. 8:1895. doi: 10.3389/fmicb.2017.01895

Conflict of Interest: The authors declare that the research was conducted in the absence of any commercial or financial relationships that could be construed as a potential conflict of interest.

Publisher's Note: All claims expressed in this article are solely those of the authors and do not necessarily represent those of their affiliated organizations, or those of the publisher, the editors and the reviewers. Any product that may be evaluated in this article, or claim that may be made by its manufacturer, is not guaranteed or endorsed by the publisher.

Copyright (c) 2021 Waghunde and Sabalpara. This is an open-access article distributed under the terms of the Creative Commons Attribution License (CC BY). The use, distribution or reproduction in other forums is permitted, provided the original author(s) and the copyright owner(s) are credited and that the original publication in this journal is cited, in accordance with accepted academic practice. No use, distribution or reproduction is permitted which does not comply with these terms. 